\title{
White blister disease control in radish seed crops
}

\author{
Mark Braithwaite ${ }^{1, \star}$, Richard Chynoweth ${ }^{2}$, Matilda Gunnarsson ${ }^{2}$, Lewis Braithwaite ${ }^{1}$, \\ Ian Harvey $^{3}$ and Phil Rolston ${ }^{2}$ \\ ${ }^{1}$ Plant Diagnostics Ltd, PO Box 23122, Hornby, Christchurch 8441, New Zealand \\ ${ }^{2}$ Foundation for Arable Research (FAR), PO Box 32133, Hornby, Christchurch 8441, New Zealand \\ ${ }^{3}$ Plantwise Services Ltd, PO Box 69181, Lincoln 7640, New Zealand \\ *Corresponding author: mark@plantdiagnosticslimited.co.nz
}

\begin{abstract}
Albugo candida is a significant pathogen of many brassica species causing leaf spotting but, more importantly, hypertrophy of flowering stems ("stagheads") resulting in yield loss. No chemicals are currently registered for white blister control in New Zealand. Little research has been carried out on white-blister management. The implications of seed transmission and subsequent disease expression in radish are not fully understood and control has relied on products containing metalaxyl-m+mancozeb. A range of fungicides were evaluated in two field trials and a pot trial for both efficacy against the disease and effect on radish yield. While metalaxyl- $m+$ mancozeb improved yields in field trials and provided good disease suppression in pot trials, the fungicides azoxystrobin, boscalid+pyraclostrobin and cyazofamid were also equally effective or better than metalaxyl-m+mancozeb. Treatments were able to suppress leaf spotting by up to $90 \%$ and inflorescence infection by $50 \%$. Seed yield increases of up to $67 \%$ were recorded. Potential new control options for white blister were identified providing alternatives to metalaxyl-m+mancozeb and thus contributing to an anti-resistance strategy.
\end{abstract}

Keywords Albugo candida, white blister, radish seed yield, oospores, chemical control.

\section{INTRODUCTION}

White blister (or white rust) is a disease caused by the oomycete pathogen Albugo candida. Other important oomycete pathogens include those causing downy mildews (e.g. Hyaloperonospora sp. on brassicas), Phytophthora spp. and Pythium spp. Albugo candida is an important obligate pathogen of many brassica species and has recently been identified as causing serious issues on radish (Raphanus sativus) seed crops in New Zealand (FAR 2016) and Australia (Minchinton et al. 2005). At least one third of the world's hybrid radish seed production occurs in the Canterbury region of New Zealand (Thomas Chin, NZ Grain and Seed Association, pers. comm.). The pathogen causes leaf spots but, more importantly, infections of the inflorescence produce hypertrophy (tissue enlargement), resulting in "stagheads" that can lead to economic yield loss (Rimmer et al. 2007). Several races of the pathogen with varying degrees of host specificity have also been reported (Kaur et al. 2011).

Albugo candida produces two spore types, asexual sporangia produced in the white blister lesions and sexual oospores which develop in any diseased tissues from either a systemic or local infection. Oospores are resistant to adverse environmental conditions and can survive in plant debris, soil or contaminated seed for several seasons (CABI 2016). Initial leaf symptoms are commonly seen evenly distributed throughout a paddock, not in foci like many other diseases. This distribution pattern indicates either highly mobile spores, such as airborne sporangia, or a widespread inoculum source such as soil or seed. 
Spread of sporangia occurs through wind, rain or insect dispersal (Agriculture Victoria 2017).

White blister is currently controlled in New Zealand with products containing a mixture of the active ingredients metalaxyl-m+mancozeb used both as a seed treatment and as foliar sprays. However, although these products have a label claim for the control of downy mildew in brassicas and crucifers in New Zealand, they are not specifically registered for white blister control. Resistance to metalaxyl by the oomycete group of pathogens has been reported overseas (Fisher \& Hayes 1984) and reliance in New Zealand on one fungicide could ultimately lead to reduced control of white blister in brassica crops.

This paper reports on two field trials and a pot trial aimed at finding alternative chemicals for disease control to identify fungicides that meet resistance management guidelines.

\section{MATERIALS AND METHODS Efficacy trials}

Fungicides evaluated for the suppression of white blister on radish both in the field and in the greenhouse are listed in Table 1.

\section{Field Trials}

Two field trials were established on commercial properties to evaluate efficacy of foliar fungicides for control of $A$. candida. The growers managed all inputs (fertiliser, weed control and irrigation) except fungicide applications. Trial 1 was established in spring-sown European round radish located near Southbridge, Canterbury (43 50' 51.97" S; $172^{\circ} 15^{\prime} 57.05 \mathrm{E}$ ) in the 2014/15 season. In addition to an untreated control, there were five fungicide treatments (Table 2) with four sequential application dates; pre-flowering at 8 to 10 leaf growth stage (24 November 2014), early flowering (19 December), mid-full flowering (14 January 2015) and end of flowering-early pod formation (23 February). There were four replicates in a randomised block design. Plots were $3.2 \mathrm{~m}$ wide by $14 \mathrm{~m}$ long (covering 2 female beds, each 8 rows wide with a male bed of 4 rows between them). Fungicide applications were made with a $3.2 \mathrm{~m}$ wide spray boom with 110015 nozzles with treatments applied at $210 \mathrm{kPa}$ in either $500 \mathrm{~L} / \mathrm{ha}$ water for the metalaxyl-m+mancozeb or $250 \mathrm{~L} /$ ha water for the other treatments.

Table 1 Products evaluated for suppression of Albugo candida on radish

\begin{tabular}{|c|c|c|c|c|c|}
\hline \multirow[t]{2}{*}{ Fungicide } & \multirow[t]{2}{*}{ Active Ingredient (ai) } & & \multicolumn{3}{|c|}{ Trials applied in: } \\
\hline & & & Pot & Field 1 & Field 2 \\
\hline Amistar $\mathrm{SC}^{\circledR}$ & azoxystrobin & $250 \mathrm{~g} / \mathrm{L}$ & $\mathrm{X}$ & $\mathrm{X}$ & $\mathrm{X}$ \\
\hline Foschek $^{\circledR}$ & phosphorous acid & $400 \mathrm{~g} / \mathrm{L}$ & $\mathrm{X}$ & & $\mathrm{X}$ \\
\hline $\operatorname{Max} \mathrm{CL}^{\circledR}$ & chlorothalonil+metalaxyl & $375+50 \mathrm{~g} / \mathrm{L}$ & & $\mathrm{X}$ & \\
\hline Pristine $^{\circledR}$ & boscalid+pyraclostrobin & $252+128 \mathrm{~g} / \mathrm{L}$ & & $\mathrm{X}$ & $\mathrm{X}$ \\
\hline Proline $^{\circledR}$ & prothioconazole & $250 \mathrm{~g} / \mathrm{L}$ & & & $\mathrm{X}$ \\
\hline $\operatorname{Ranman}^{\circledR}$ & cyazofamid & $400 \mathrm{~g} / \mathrm{L}$ & $\mathrm{X}$ & & \\
\hline Ridomil Gold MZ ${ }^{\circledast}$ & metalaxyl-m+mancozeb ${ }^{1}$ & $40 \mathrm{~g}+640 \mathrm{~g} / \mathrm{kg}$ & $\mathrm{X}$ & $\mathrm{X}$ & $\mathrm{X}$ \\
\hline Seguris Flexi ${ }^{\circledR}$ & isopyrazam & $125 \mathrm{~g} / \mathrm{L}$ & $\mathrm{X}$ & & $\mathrm{X}$ \\
\hline
\end{tabular}

${ }^{1}$ Current industry standard 
Table 2 Evaluation of five fungicide treatments in a field trial (Trial 1) with two assessment dates (29 January and 23 February 2015) for the control of Albugo candida in radish during the 2015/16 growing season

\begin{tabular}{|c|c|c|c|c|}
\hline & Amount/ha & $\begin{array}{r}\text { Assessment } 1 \\
\% \text { Racem }\end{array}$ & $\begin{array}{l}\text { Assessment } 2 \\
\text { es infected }\end{array}$ & $\begin{array}{l}\text { Yield } \\
\mathrm{kg} / \mathrm{ha}\end{array}$ \\
\hline Untreated & & $64 \mathrm{a}$ & $71 \mathrm{a}$ & $588 \mathrm{c}$ \\
\hline Metalaxyl-m+mancozeb ${ }^{1}$ & $2.0 \mathrm{~kg}$ & $59 \mathrm{a}$ & $53 \mathrm{ab}$ & $676 \mathrm{ab}$ \\
\hline Metalaxyl-m+mancozeb ${ }^{1}$ & $3.0 \mathrm{~kg}$ & $50 \mathrm{ab}$ & $53 \mathrm{ab}$ & $634 \mathrm{bc}$ \\
\hline Chlorothalonil+metalaxyl ${ }^{2}$ & $2.4 \mathrm{~L}$ & $64 \mathrm{a}$ & $56 \mathrm{ab}$ & $627 \mathrm{bc}$ \\
\hline Azoxystrobin & $1.0 \mathrm{~L}$ & $18 \mathrm{c}$ & $26 c$ & $728 \mathrm{a}$ \\
\hline Boscalid+pyraclostrobin & $400 \mathrm{~g}$ & $31 \mathrm{~cd}$ & $40 \mathrm{bc}$ & $681 \mathrm{ab}$ \\
\hline Mean & & 48 & 50 & 655 \\
\hline P Value & & 0.0037 & 0.011 & 0.028 \\
\hline CV\% & & 34 & 29 & 8 \\
\hline LSD 0.05 & & 24 & 22 & 80 \\
\hline Significance ${ }^{3}$ & & ** & * & * \\
\hline
\end{tabular}

${ }^{1}$ Applied as Ridomil Gold MZ, the current industry standard

2 Applied as Max CL

${ }^{3 *}$ Significant at $\mathrm{P}=0.05 ;{ }^{* *}$ significant at $\mathrm{P}=0.01$

White blister infection was assessed on two dates: 29 January and 4 March 2015. The numbers of infected racemes were counted, and data presented as the percentage of infected racemes per plot. The plots were desiccated with diquat and direct harvested with a $1.35-\mathrm{m}$ wide plot combine harvester on 13 April. The seed was cleaned and sized into 3 diameters: $>3.0 \mathrm{~mm}$; 2.6 to $3.0 \mathrm{~mm}$; and $<2.6 \mathrm{~mm}$. The seed yield was calculated using seed $>2.6 \mathrm{~mm}$ in diameter. Seventy-five percent of the seed was in the $>3.0$ mm diameter size.

Trial 2 was established in hybrid red round radish located near Southbridge (43 $37^{\prime} 40.90^{\prime \prime}$ S; $\left.172^{\circ} 13^{\prime} 50.56 \mathrm{E}\right)$ in the $2016 / 17$ growing season. The trial was established early October with plot size and layout as in Trial 1. There were 6 fungicide treatments (Tables 1 and 3 ) and an untreated control with four replicates in a randomised block design. Fungicide applications were applied as in Trial 1 . There were 6 fungicide applications starting on the 12 December 2016 at approximately 14-day intervals. Treatment 3 received an initial azoxystrobin on the 10 October
2016 when cotyledons had emerged. Disease was assessed as in Trial 1 on five dates from 1 December 2016 to 1 March 2017. Harvesting and seed cleaning was as described for the Trial 1.

\section{Pot trial}

Young radish plants from four separate hybrid radish seed-lines $(3,4,6$, and 16$)$ were grown in a shade-house at Lincoln University and hand watered as required along with some automatic irrigation from overhead sprinklers. Pre-bolting plants showing white blister symptoms, were selected for fungicide evaluation to control A. candida. Initial levels of disease in the plants were statistically similar for the four lines (disease score range of $0.83-1.17$ on a scale of $0-5$ (see below), data not presented. Equal numbers of plants were selected from each of the four seed-lines (three duplicate plants per treatment to provide even levels of disease across the experiment). Plants were grown in individual planter bags (PB 1.5) in a standard Lincoln University peat/pumice mix. There was one plant per planter bag and these were arranged into a 
Table 3 Evaluation of six fungicide treatments in a field trial (Trial 2) for the control of Albugo candida in radish during the $2016 / 17$ growing season

\begin{tabular}{lcccc}
\hline Treatment & $\#^{2}$ & $\begin{array}{c}\text { Rate } \\
(\mathrm{kg} \mathrm{or} \mathrm{L} / \mathrm{ha})\end{array}$ & $\begin{array}{c}\text { Disease }^{3} \\
(\%)\end{array}$ & $\begin{array}{c}\text { Yield } \\
(\mathrm{kg} / \mathrm{ha})\end{array}$ \\
\hline Untreated & 0 & & $58 \mathrm{a}$ & $933 \mathrm{~b}$ \\
Metalaxyl-m+mancozeb $^{1}$ & 6 & $2.5 \mathrm{~kg}$ & $45 \mathrm{bc}$ & $1258 \mathrm{a}$ \\
$\begin{array}{l}\text { Azoxstrobin then metalaxyl-m } \\
\quad \text { mancozeb1+azoxystrobin }\end{array}$ & $1+6$ & $0.75 / 2.5+0.75$ & $43 \mathrm{bc}$ & $1503 \mathrm{a}$ \\
Boscalid+pyraclostrobin & 6 & $1.5 \mathrm{~L}$ & $38 \mathrm{c}$ & $1519 \mathrm{a}$ \\
Isopyrazam+azoxystrobin & 6 & $0.5+0.5 \mathrm{~L}$ & $38 \mathrm{c}$ & $1558 \mathrm{a}$ \\
Prothioconazole & 6 & $0.5 \mathrm{~L}$ & $50 \mathrm{ab}$ & $913 \mathrm{~b}$ \\
Phosphorus acid & 6 & $0.5 \mathrm{~L}$ & $50 \mathrm{ab}$ & $796 \mathrm{~b}$ \\
\hline Mean & & & 46 & 1211 \\
P Value & & & 0.015 & $<0.001$ \\
CV\% & & & 17 & 10 \\
LSD 0.05 & & 11 & 315 \\
Significance & & $*$ & $* * *$ \\
\hline
\end{tabular}

${ }^{1}$ Note different rate to that used in Trial 1.

${ }^{2}$ Number of fungicide applications

${ }^{3}$ Percent racemes with infection with Albugo candida at the final assessment

$4 *$ Significant at $\mathrm{P}=0.05$; ${ }^{* *}$ significant at $\mathrm{P}=0.001$

randomised complete block design consisting of five blocks with five fungicide treatments and a water control (replicated twice). Plants were hand watered as required plus the shadehouse was automatically watered from overhead sprinklers. The fungicide treatments (Table 4) were applied twice, 12 days apart on 11 February and 23 February 2017. Fungicides were diluted in $500 \mathrm{~mL}$ of water and applied using a hand-held sprayer to incipient run-off. Plants were assessed for disease on 10 March 2017, 15 days after the final fungicide spray. The total number of leaves per plant, white blister lesions per plant and an overall disease score (a scale of 0 to 5 where: $0=$ no lesions observed; $1=$ scattered lesions on the lower leaves; $2=$ low numbers of lesions on the lower leaves and scattered lesions on the upper leaves; $3=$ moderate number of lesions on the lower leaves; low level of lesions on the upper leaves $4=$ moderate to high numbers of lesions on the lower leaves; greater than 200 per leaf and moderate number of lesions on the upper leaves,
$5=$ moderate to heavy number of lesions over the whole plant, greater than 200 per any one leaf) were recorded. A second assessment was conducted on 2 May 2017 to evaluate the effect of the fungicide sprays on white blister "staghead" development.

\section{Statistical analyses}

All data were subjected to analysis of variance (ANOVA) for randomised block designs using R ( $\mathrm{R}$ Core Team 2014). Differences between treatment means were assessed by the unrestricted least significant difference (LSD) method at $\mathrm{P}=0.05$.

\section{RESULTS}

\section{Field trials}

In Trial 1, there was high disease pressure in the untreated control with $71 \%$ of racemes infected at the time of the final assessment. Azoxystrobin and boscalid+pyraclostrobin reduced $(\mathrm{P}=0.011)$ the disease incidence compared with the 
Table 4 Evaluation of five fungicide treatments for the control of Albugo candida on radish plants (pot trial). Fungicides applied at early bolting and again two weeks later.

\begin{tabular}{lcccc}
\hline Treatment & Rate & $\begin{array}{c}\text { Mean Lesions } \\
\text { per Plant }\end{array}$ & $\begin{array}{c}\text { Disease } \\
\text { Score } \\
(0-5)\end{array}$ & $\begin{array}{c}\text { "Mean Staghead" } \\
\text { Lesion Length per } \\
\text { Plant }(\mathrm{mm})\end{array}$ \\
\hline Water (control) & - & $125.18 \mathrm{a}$ & $3.58 \mathrm{a}$ & $50.1 \mathrm{ab}$ \\
Metalaxyl-m+mancozeb $^{1}$ & $2.5 \mathrm{~g} / \mathrm{L}$ & $41.35 \mathrm{c}$ & $1.80 \mathrm{~b}$ & $34.2 \mathrm{~b}$ \\
Isopyrazam $_{\text {Cyazofamid }}^{2}$ & $2.4 \mathrm{~g} / \mathrm{L}$ & $91.40 \mathrm{~b}$ & $3.10 \mathrm{a}$ & $34.7 \mathrm{ab}$ \\
Azoxystrobin & $0.8 \mathrm{~mL} / \mathrm{L}$ & $0.65 \mathrm{~d}$ & $0.35 \mathrm{c}$ & $71.6 \mathrm{ab}$ \\
Phosphorous acid & $3.0 \mathrm{~mL} / \mathrm{L}$ & $1.50 \mathrm{~d}$ & $0.40 \mathrm{c}$ & $72.6 \mathrm{a}$ \\
Mean & $5.0 \mathrm{~mL} / \mathrm{L}$ & $68.75 \mathrm{bc}$ & $2.30 \mathrm{~b}$ & $35.5 \mathrm{ab}$ \\
P Value & & 54.80 & 1.92 & 49.8 \\
CV\% & $<0.001$ & $<0.001$ & 0.185 \\
LSD 0.05 & & 90 & 48 & 122 \\
Significance & & 31.2 & 0.59 & 38.2 \\
\hline
\end{tabular}

${ }^{1}$ Same rate as used in Trial 2

${ }^{2}$ cyazofamid was applied with Duwett (organosilicone wetting agent) at a rate of $0.5 \mathrm{~mL} / \mathrm{L}$

${ }^{3} \mathrm{NS}=$ not significant; ${ }^{* *}$ significant at $\mathrm{P}=0.001$

unsprayed treatment (Table 2). These two fungicide treatments, along with metalaxyl$\mathrm{m}+$ mancozeb at $2 \mathrm{~kg}$ product per ha, also increased $(\mathrm{P}=0.028)$ the final seed yield by up to $19 \%$. Azoxystrobin provided better control than metalaxyl-m+mancozeb (Table 2).

In Trial 2, disease levels were initially low, building to moderate to high levels with $58 \%$ of racemes infected in the untreated plots by the time of the final assessment in early March. There were no differences in percent infection until the final assessment where metalaxyl- $m+$ mancozeb, metalaxyl-m+mancozeb+azoxystrobin, boscalid+ pyraclostrobin and isopyrazam+azoxystrobin all reduced $(\mathrm{P}=0.015)$ the percentage disease compared with the unsprayed treatment (Table $3)$. These four treatments also increased $(\mathrm{P}<0.001)$ final seed yield compared with the untreated plots. Prothioconazole and phosphorous acid used in this trial did not control white blister.

\section{Pot trial}

All treatments reduced $(\mathrm{P}<0.05)$ the mean number of white blister lesions per plant with cyazofamid and azoxystrobin resulting in the lowest number of lesions (Table 4). Use of isopyrazam did not reduce the disease score compared with the untreated control. The other five treatments did reduce the disease score compared with the untreated control, with phosphorous acid being the least effective of these. No treatments affected mean "staghead" lesion length per plant.

\section{DISCUSSION}

Two field trials and a pot trial evaluated a range of fungicides for the control of white blister on radish. Currently, producers of radish seed rely on a single fungicide treatment, metalaxyl$\mathrm{m}+$ mancozeb, but this research has identified other chemicals with different structures and modes of action able to provide equal or better control, improve yield and offer anti-resistance strategies in line with current guidelines.

Metalaxyl-m+mancozeb has been the industry standard for control of white blister and other oomycete pathogens (CABI 2016) and has provided acceptable control. However, resistance to this fungicide by other oomycete pathogens suggest that the efficacy of this chemical may be at risk. Resistance has been identified in the 
oomycete pathogens Phytophthora spp. (Matson et al. 2015), Pythium spp. (Cook \& Zhang 1985) and downy mildew (Molinero-Ruiz 2010) but had not currently been reported in Albugo candida.

Results of the pot trial suggested that alternative chemicals such as cyazofamid and azoxystrobin may provide a better reduction of disease severity compared with metalaxyl$m+$ mancozeb (number of lesions per leaf). The results of the pot trial for metalaxyl-m+mancozeb and azoxystrobin were consistent with the field trial data, with both these treatments providing reduced disease levels and improved seed yields over both field trials. An additional fungicide, boscalid+pyraclostrobin, also provided equivalent disease control and improved seed yield. However, phosphorous acid, a chemical effective against other oomycetes performed poorly in the field and in the glasshouse experiments. Similarly, prothioconazole was not effective in controlling white rust.

The lack of efficacy on the formation of "stagheads" in the pot trial was surprising but may reflect the length of time from flowering (time of the last fungicide application) and seed formation, with a likely degradation effect of the fungicides within the plants.

The greater seed yield response to fungicide treatments in Trial 2 (36\%) compared to Trial 1 (23\%) may reflect the increased number of fungicide applications (6 versus 4) in Trial 2. The use of fungicide mixtures in Trial 2 provided equivalent disease control and yield improvements to metalaxyl-m+mancozeb. This combined with alternative chemicals to metalaxyl-m+mancozeb offers the industry a good anti-resistance strategy either through alternating or combining chemicals with different modes of action.

\section{ACKNOWLEDGEMENTS}

We thank Bronwyn Braithwaite and Emily Hicks for setting up, managing, spraying and assistance with scoring the pot trial and comments on the manuscript. NZ Arable are thanked for spraying and maintaining the field trials. These experiments were funded by the Foundation for Arable Research.

\section{REFERENCES}

Agriculture Victoria 2017. Management of white blister. http://agriculture.vic.gov.au/ agriculture/pests-diseases-and-weeds/plantdiseases/vegetable/white-blister-on-broccoli/ management-of-white-blister

CABI 2016. Crop Protection compendium datasheet for Albugo candida (white rust of crucifers). Wallingford, UK.

Cook RJ, Zhang BX 1985. Degrees of sensitivity to metalaxyl within the Pythium spp. pathogenic to wheat in the Pacific Northwest. Plant Disease 69: 686-688.

FAR 2016. White blister (white rust) disease in radish. Arable Updates - Vegetable Seeds 3. Foundation for Arable Research, Christchurch, New Zealand: 4 pp.

Fisher DJ, Hayes AL 1984. Studies of mechanisms of metalaxyl fungitoxicity and resistance to metalaxyl. Crop Protection 3: 177-184.

Kaur P, Sivasithamparam K, Barbetti MJ 2011. Host range and phylogenetic relationships of Albugo candida from cruciferous hosts in Western Australia, with special reference to Brassica juncea. Plant Disease 95: 712-718.

Matson MEH, Small IM, Fry ME, Judelson HS 2015. Metalaxyl resistance in Phytophthora infestans: assessing role of RPA190 gene and diversity within clonal lineages. Phytopathology 105: 1594-1600.

Molinero-Ruiz ML, Cordón-Torres MM, Martínez-Aguilar J, Melero-Vara M, Domínguez J 2010. Resistance to metalaxyl and to metalaxyl-M in populations of Plasmopara halstedii causing downy mildew in sunflower. Canadian Journal of Plant Pathology 30: 97-105.

Minchinton EJ, Galea V, Thomson F, Trapnell L, 
Murdoch C, Nadesan S, Kita N 2005. Disease management strategies for downy mildew on spring onions and white blister on radish. Horticulture Australia Ltd, Final Report: VG01045. Department of Primary Industries, Victoria, Australia. Pp. 35-37.

RCore Team 2014. R: A language and environment for statistical computing. R Foundation for Statistical Computing, Vienna, Austria. URL http://www.R-project.org/.

Rimmer SR, Shattuck VI, Buchwaldt L (eds) 2007. Compendium of brassica diseases, APS Press, St Paul, MN, USA. Pp. 54-56. 